Strategy Study

\title{
Cyberspace, Censorship, and the Constitution
}

\section{Anna Lorien Nelson}

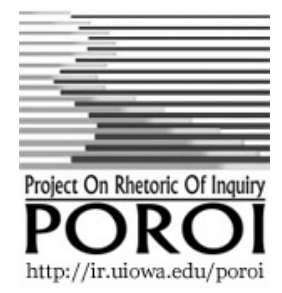

Poroi, 3, 1, J une, 2004

1 In J une 2003, the Supreme Court declared high-tech censorship constitutional.

2 Congress passed the Children's Internet Protection Act, or CIPA, in 1999. The law requires all publicly funded libraries to electronically regulate the access of patrons to the World Wide Web. The "filtering software" is far from perfect. It partly fails in its primary aim: shielding underage eyes from pornography. Worse, the software censors massive quantities of legitimate information from children and adults alike.

3 The Supreme Court's 6-3 vote in United States v. American Library Association obscures an ominous detail. Only four justices bothered to acknowledge that censoring public access to cyberspace is a First Amendment issue. Four justices outright denied it. They called the legislation a mere matter of purse strings, declaring that Congress can dictate rules to institutions that take federal funds. The Court's ninth justice, Kennedy, made vague noises of sympathy for "constitutionally protected Internet material" but voted to uphold the law. As Kennedy loitered on the fence, the First Amendment slipped through its pickets.

4 There are five things wrong with the US v. ALA decision. The purse-strings argument is almost as faulty as the filtering technology; and the Court misconceives censorship, federalism, and what libraries are for. As a scholar of law and politics, but especially as a former librarian, I criticize from experience. Perhaps these credentials add weight to the arguments to come. The wonder of the Web, though, is that I don't have to have such credentials to be heard. Were this article not printed in a journal, I could post it online myself. The question after US v. ALA is: who will be able to read it? 


\section{Webs of Information and Tangles of Purse Strings}

5 How could Rehnquist, O'Connor, Scalia, and Thomas argue that the First Amendment has no bearing on the Children's Internet Protection Act? The J ustices focused instead on the "spending clause" of the Constitution (Article $1, \S 8$ ). Congress gets great leeway in attaching conditions to funding. Thus the Chief J ustice dismissed the American Library Association's concerns about censorship with a wave of his hand: "To the extent that libraries wish to offer unfiltered access," he wrote, "they are free to do so without federal assistance."

6 The claim sounds straightforward. If Congress foots the bill, Congress calls the shots. Upon closer inspection, though, the picture complicates. Several pieces of legislation fund American public libraries. The Telecommunications Act of 1996 established the "E-Rate" program, which enables libraries to purchase Internet access at reduced rates. The Library Services and Technology Act of 1996 funds technologies to share information among libraries and other community services. It also fosters programs to make library resources more accessible to urban, rural, and low-income citizens. These laws, taken with the Court's latest ruling, suggest that the government might rightly regulate any detail of library operations. Is this what we want? Schools are an obvious example, akin to libraries in their provisions of information to the public. Do we take this tangle of federal purse strings to mean that President Bush can tell us what to teach? Could he, a conservative Christian, order us to learn creationism instead of evolutionary theory? Of course not. Courts have repeatedly struck down similar curricular requirements set by state laws. Federal funding cannot require rules in conflict with our basic freedoms.

7 Even if we accept that money comes with strings attached, sweeping censorship remains inappropriate. The Children's Internet Protection Act stretches regulation far beyond the scope of its funding. "The Government does not merely seek to control a library's discretion with respect to computers purchased with Government funds or those computers with Governmentdiscounted Internet access," noted J ustice Stevens. "CIPA requires libraries to install filtering software on every computer with Internet access if the library receives any discount from the E-Rate program or any funds from the LSTA program." 
8 The bottom line is that rights are worthless without means to exercise them. When Rehnquist declared libraries free to offer Internet access without federal assistance, he ignored the reality that every public library relies on public funding to function. Spring 2003 provided a poignant illustration: The nation's first public library, founded by Ben Franklin, nearly closed its doors. Our economic recession has forced steep budget cuts at the state level, and libraries have been frontline casualties. The Franklin Public Library remains open today thanks to an $\$ 18,000$ federal grant. When the Chief J ustice contrasted outright penalties and a (mere) lack of subsidies, Stevens correctly called the distinction immaterial: "An abridgment of speech by means of a threatened denial of benefits can be just as pernicious as an abridgment by means of a threatened penalty."

9 Rehnquist acknowledged - yet managed to ignore - the precedent of Board of Commissioners, Wabaunsee County v. Umbehr (1996), where the Court opined that "the government 'may not deny a benefit to a person on a basis that infringes his constitutionally protected ... freedom of speech' even if he has no entitlement to that benefit." As the Court affirmed the capacity of Congress to attach conditions to the receipt of aid in South Dakota v. Dole (1987), it nevertheless stipulated that Congress could not compel the recipient "to engage in activities that would themselves be unconstitutional." Try as they might, Rehnquist, O'Connor, Scalia, and Thomas could not entirely escape the clutches of the Constitution through the trapdoor of the "spending clause." The First Amendment demanded attention.

\section{A Tradition of Libraries as Social Forums}

10 Forced to address the First Amendment, Rehnquist asserted that libraries are for listening, not speaking. Thus library restrictions would not fall within the purview of the First Amendment. Arguing that a right to speech does not imply a right to be heard makes about as much sense as arguing that withholding essential funding is deeply different from enforcing a penalty. Each claim seems silly in the real world. The District Court reviewing US v. ALA disagreed with the Supreme Court, likening Internet access in public libraries to "traditional public fora ... such as sidewalks and parks" because it "promotes First Amendment values in an analogous manner." In the Library Services and Technology Act, Congress encouraged libraries to continue serving "social" as well 
as "educational" and "informational" purposes. Yet Rehnquist wrote, "The public forum principles on which the District Court relied are out of place in the context of this case. Internet access in public libraries is neither a 'traditional' nor a 'designated' public forum." Incredibly he continued: "This resource [the Internet] which did not exist until quite recently - has not "immemorially been held in trust for the use of the public and, time out of mind, been used for purposes of assembly, communication of thoughts between citizens, and discussing public questions."' Rehnquist concluded that "doctrines surrounding traditional public forums may not be extended to situations where such history is lacking."

11 It seems bizarre and shortsighted to dismiss the Internet as a "non-traditional" public forum. Of course the Internet has no lengthy historical tradition - it's brand new. The relevant "tradition," as Congress recognized in the Library Services and Technology Act, is the historical function of libraries in society. In other words, libraries are public forums.

12 There are two more pertinent traditions which the Court overlooks. It is eminently American to extend the spirit of constitutional protection to technologies not anticipated by founding fathers. Declaring that talk since "time out of mind" is the only constitutionally protected kind, Rehnquist ironically breaks with an American tradition of legal evolution. We broaden the constitutional shield against "unreasonable search and seizure" with wiretapping legislation. We read an unwritten right of privacy into the Fourteenth Amendment. Can we not protect speech in cyberspace?

13 Federalism, the dispersion of government power to local agencies, is a third historical norm undercut by the US v. ALA decision.

Later I return to the topic of federalism. Here it may be enough to observe that a local library, not the federal government, traditionally makes decisions about the contents of local collections. Preemptive government censorship is not an American tradition.

14 Rehnquist asserts that a lack of "traditions" excuses the US v. ALA decision. To respond, I've identified three traditions counter to the Children's Internet Protection Act. We can take a step further. We can reject altogether the necessity of proving traditions. Our world is a different place since the explosion of electronic technologies in the latter half of the twentieth century. Our libraries are different places. Even if libraries weren't public forums before the spread of 
the Internet, they are now. The J ustice Department, for instance, invites official public comment online. Recall the spirited cyberdiscussion of the Microsoft antitrust settlement. What else can we call the Internet but a public forum? What can we call libraries, but essential points of access to this public forum for people without alternative avenues for logging on? Note, too, that online commentary about Microsoft was hardly confined to clean language. This sort of government-sanctioned public debate in chat rooms and message boards does not make it past the filtering software mandated by the Children's Internet Protection Act.

15 Rehnquist's argument, at heart, is that the First Amendment is irrelevant to libraries because patrons are passive receivers of information rather than potential public speakers. His claim is insidiously self-fulfilling. The broad restrictions to Internet access established by CIPA, coupled with the legal reasoning in US v. ALA, create a climate where citizens can only express opinions in sanctioned terms, about sanctioned subjects.

16 Citizens can struggle awfully hard to express themselves freely in cyberspace. Yet the Chief J ustice denied that any such struggle could exist. He distinguished US v. ALA from Legal Services Corporation v. Velazquez (2001), where the Court ruled that a "restriction on advocacy [proposed by Congressional purse-string requirements] in welfare disputes would distort the usual functioning of the legal profession and the federal and state courts before which the lawyers appeared. ... Public libraries, by contrast, have no comparable role that pits them against the Government." That is patently false. Information is power. It is power for self-government and for democratic deliberation. To control information is to control political ideas, speech, perhaps even thought. And information is the stock-in-trade of libraries. In Velazquez, the Court concluded that federally funded institutions, when their roles pit them against the government, "must be free of any conditions that their benefactors might attach to the use of donated funds or other assistance." Libraries inform our free speech just as attorneys inform our legal defenses. Public libraries and public defenders make constitutional rights meaningful for the less fortunate.

17 Libraries are crucial places where we inform political speech. In a world with the Web, they could also be crucial places where we perform political speech. The institution of the public library has a special relationship to the First Amendment, the amendment that we give a legally "preferred position" among all our constitutional 
rights. We privilege the First Amendment because we know how vital free speech and thought are to self-government. This is specific reason why reducing the CIPA case to a spending clause dispute is wrong. Earlier I offered a more general critique of the spending clause: it would be absurd to read the spending clause as legalizing total federal control over libraries that are but partially federally funded. In fact, though, the government does assert areas of absolute control over institutions that are only partially publicly funded. How can we criticize CIPA while advocating affirmative action or Title IX programs that similarly depend on the leverage of federal funding for enforcement?

18 Affirmative action and Title IX programs enable government to protect individual rights against powerful (nongovernmental) institutions. Indeed federal prohibitions of discrimination are enforced in libraries just as in schools and other workplaces. But the nature of the CIPA funding stipulation is different: it interferes with the capacity of libraries to protect individual rights against powerful (governmental) institutions. The rationale for CIPA is that it protects younger, more innocent library patrons from their older, less savory peers. How do we resolve such a rightsprotection conflict? The legal answer is that we privilege free speech rights with a "preferred position." The pragmatic answer is that we privilege protections for individuals against institutions. Would you rather take on a handful of library patrons or the whole government?

19 Suppose that you lack the money for lawyers or law classes, but you want to learn to challenge the constitutionality of Title IX. Where can you go? The library. Now suppose you want to learn to challenge the constitutionality of library censorship. Where can you go?

\section{Technologies for Filtering Free Speech}

20 As community forums, public libraries fall squarely within the province of the First Amendment. Advocates of the Children's Internet Protection Act point to "community standards" of indecency and obscenity to justify First Amendment restrictions. The concerns that motivate the law are real. The American Library Association acknowledges that "patrons of all ages, including minors, regularly search for online pornography. ... Some patrons also expose others to pornographic images by leaving them displayed on Internet terminals or printed at library printers." What can we do to limit access to age-inappropriate 
materials? There seem to be three logical possibilities: regulation by man, machine, or a combination.

21 Filtering software required by the Children's Internet Protection Act attempts to solve the porn problem by machine. The technology has several unfortunate limitations. Computers are programmed to block categories such as "pornography" and "violence." J ustice Stevens explains, "search engines that software companies use for harvesting are able to search text only, not images. ... Image recognition technology is immature, ineffective, and unlikely to improve substantially in the near future. ... . Because of this 'underblocking' [failure to filter pornographic images unaccompanied by text] the statute will provide parents with a false sense of security without really solving the problem that motivated its enactment." Filtering software cannot completely do the job.

22 The larger problem with the software is how it "overblocks" information that citizens seek for legitimate research. When the category "violence" is blocked, democratic conversation about current events is silenced. Think of news coverage of the war on terror, the war with Iraq, the Balkan and Rwandan genocides. To preemptively censor such primary political information is criminal. Or it was criminal, until the Court upheld CIPA. As recently as 2002, justices ruled in Ashcroft v. Free Speech Coalition that "the Government may not suppress lawful speech as the means to suppress unlawful speech."

23 With automated filters, adolescents and adults cannot adequately investigate medical illnesses or healthy sexuality. The software is intended to aid youths, yet it hinders help for one of our most atrisk groups: young people with questions about sexual orientation. Gay teens have one of the highest rates of suicide in our country. The Internet is serving as a lifeline for a generation of adolescents, seeking answers to questions and simply needing to know that there are others like them out there. As these kids grow, they keep turning to the Internet - if we let them. Help is needed: suicide rates among young adults have tripled since the 1950s. As he joined an October 2003 consortium of eighty universities with mental health services online, University of Arizona President Peter Likins described the utility of anonymous Web access. "Oftentimes, people in depression are not able to go to mental health services that are available. They're embarrassed," he explained. "Some of these youngsters may be willing to explore 
on the Internet and get some anonymous feedback."

24 Unfiltered, the Internet allows youths as well as their parents a safe anonymity to find assistance with a host of taboo social ills from alcohol and drug addictions, to depression and suicidal thoughts, to physical and sexual abuse. Filtering software puts these subjects off-limits, because computers can't tell a website that celebrates snuff films from a support site for survivors of domestic violence. Key words like "rape" and "torture" surface both places.

25 Despite having worked in library computer labs, I don't have stories to tell about kids using the Internet to get help. That's precisely the point: CIPA costs us anonymity. The story I can tell you, however, is about cleaning all the library shelves last spring. The section of adolescent help books (on suicide, anorexia, abuse) was particularly filthy with fingerprints and food crumbs: its books were much handled. These shelves were a far cry from our pristinely dusty rows of books on modern art and medieval history. Curiously I thumbed through some of the help books. Their checkout records, the sheets where we stamp due dates, were bare. If so many hesitate to check out books face-to-face from librarians, how many will request Internet filter overrides?

26 The Supreme Court acknowledged the grave limitations of automated filters. A majority of justices overcame their apprehensions by assuming that a combination of human intervention with technological innovation could keep kids and speech safe. "If, on the request of an adult user, a librarian will unblock filtered material or disable the Internet software filter without significant delay, there is little to this case," Kennedy wrote. "If some libraries do not have the capacity to unblock specific Web sites or to disable the filter or if it is shown that an adult user's election to view constitutionally protected Internet material is burdened in some other substantial way, that would be the subject for an as-applied challenge." In other words, Kennedy told the American Library Association and the American Civil Liberties Union to come back with a more specific complaint. Placing this burden of evidence on defenders of the First Amendment is inappropriate. The Supreme Court previously outlawed the "prior restraint" of expression, but that is exactly what filtering software does.

27 The Children's Internet Protection Act provides no legal definition of "bona fide" research. "We are here to review a statute," Souter 
explained, "and the unblocking provisions simply cannot be construed, even for constitutional avoidance purposes, to say that a library must unblock upon adult request." The preemptive use of filters turns librarians into gatekeepers. No librarian I know wants this job. Nor would many citizens want to give such responsibility to librarians.

28 Yes, we live in a country where handfuls of librarians - although not the ones I know - keep banning books like Harry Potter for references to the occult or Huckleberry Finn for use of the term "nigger." Twain's masterpiece is available on the Internet because its copyright has expired. But if you look it up in a public library that searches Web text for the " $n$ " word, you won't be able to read the American classic online. That word also figures in the hate speech that filters target. Why should this matter, as long as we have hard copies of Huck? One answer is that electronic texts allow unique opportunities to analyze arguments, automating word searches to measure patterns in language. The biggest problem with filters, though, is that requiring citizens to seek caseby-case permission to access online content has an extraordinarily chilling effect. It is precisely the people who need help most - the poor, abused, or socially isolated - who are least likely to anticipate (or, perhaps, to receive) sympathetic assistance from librarians.

29 Rehnquist replies that "close monitoring of computer users [by library staff] would be far more intrusive than the use of filtering software." Point taken. Here, though, the Chief J ustice suffers a simple lack of imagination. Librarians looking over the shoulders of everyone is not the only alternative to automated censorship by computer. There are other ways to organize library supervision by man more than machine. It is not hard to separate a supervised area for children's computers from an unsupervised set of terminals for adults. Many libraries do this already. Another practice common among libraries is to institute time limits for computer use during busy periods of the day, stifling surfers who might otherwise troll endlessly for porn.

30 Low-tech alternatives to CIPA are superior for reasons beyond the Constitution. The possibility of inappropriate use of the Internet by youths is an argument for adult supervision, not an excuse to shift responsibility for our kids onto inadequate software. Kids in libraries need supervision anyway: they shout, vandalize, and occasionally wreak broader havoc. Filtering software can't save the money for staffing this sort of supervision. And if, as Rehnquist 
suggests, librarians are eminently accessible to flip filtering software on and off, what does filtering software save in staff hours? "The District Court expressly found that a variety of alternatives less restrictive are available at the local level," Stevens noted dryly.

\section{Always Choose the Lesser of Two Evils: A Federalist Principle for Protecting Free Speech}

31 Mine is a political argument about how and why we protect our freedoms. It is not a close legal analysis of the CIPA decision. Here I quote more often from dissenting than plurality views, and I do not aim for a more meticulous scholarship. Instead I write as a fan of the First Amendment who distrusts the "prior restraints," the "time, place, and manner restrictions," and even the "community standards" that the Supreme Court allows for censoring indecent and obscene material. No more do I want local control over free speech than I want national control of it.

32 From living in both, I appreciate that there can be a world of difference between the small-town Midwest and the big-city East. I recognize that cultural definitions of art and decency vary, and I know that some communities would install filtering software in their libraries with or without the Children's Internet Protection Act. Before legislation mandated the software, almost seventeen percent of public libraries used filters on at least some of their Internet terminals. Seven percent had filters on all of them. But if libraries are going to use filtering software, where should the directive arise? The legal doctrine of "community standards" emphasizes that First Amendment restrictions should be formulated by local authorities. If the decision to filter the Internet is left to individual communities, we can cross our fingers that not all will choose censorship. "Rather than allowing local decision makers to tailor their responses to local problems," Stevens lamented, "the Children's Internet Protection Act operates as a blunt nationwide restraint on adult access to 'an enormous amount of valuable information' that individual librarians cannot possibly review. ... Most of that information is constitutionally protected speech."

33 Although my libertarian propensity is to label local control "the lesser of two evils," I find cause for optimism in fellow librarians. After September 11, Congress adopted the USA PATRIOT Act 
(2001). It empowers federal law enforcers to seek search warrants for library records. The Bush Administration touted the law's potential to identify and incriminate terrorists. The mere act of reading books on bombs, biotechnology, or mental illness can be used against defendants. In response, many librarians have retooled their catalog systems to reduce the information kept on patrons. The government can't get what librarians don't have. No doubt there are librarians somewhere keeping records as detailed as ever, despite the consequences for the civil rights of their patrons. When First Amendment decisions (good or bad) are made at a local level, at least there is recourse to the "strict scrutiny" of content-based restrictions by higher courts. But if the Supreme Court writes Congress a blank check to require universal content restrictions, as it has done in USv. ALA, where is the recourse? What happens to our system of checks and balances? This is where freedom of speech is supposed to serve us most vitally, as an essential political tool. But this is where freedom of speech is getting stomped by the Supreme Court.

\section{Selecting Books and Censoring Speech: Two Sides of a Coin?}

34 The most compelling arguments for the Children's Internet Protection Act are flawed analogies. Rehnquist asserted that "strict scrutiny" of Congressional censorship of libraries is not warranted because "such a limiting and rigid test would unreasonably interfere with the discretion inherent in the 'selection' of a library's collection." Generally the District Court conceded, "the First Amendment subjects libraries' content-based decisions about which print materials to acquire for their collections to only rational [basis] review." The standard of rational review requires the government merely to show that a speech restriction furthers a "compelling state interest." Here the compelling concern is child protection. "Most libraries already exclude pornography from their print collections because they deem it inappropriate for inclusion," Rehnquist elaborated. "We do not subject these decisions to heightened scrutiny; it would make little sense to treat libraries' judgments to block online pornography any differently, when these judgments are made for just the same reason." (The point Rehnquist misses, even in his own words, is that these are decisions libraries make, not the federal government.) 
35 Libraries are allowed to be selective because resources are limited, not because censorship is otherwise acceptable. The Internet, therefore, is a whole different game from books. "In the instance of the Internet, what the library acquires is electronic access, and the choice to block is a choice to limit access that has already been acquired. Thus deciding against buying a book means there is no book (unless a loan can be obtained), but blocking the Internet is merely blocking access purchased in its entirety and subject to unblocking if the librarian agrees. The proper analogy," Souter dissented, "is not to passing up a book that might have been bought; it is either to buying a book and then keeping it from adults lacking an acceptable 'purpose,' or to buying an encyclopedia and then cutting out pages with anything thought to be unsuitable for all adults."

36 Waffling, Breyer sympathized with Souter but voted with Scalia. He drew a second flawed analogy, comparing the use of electronic filters with the segregation of print materials in closed stacks. Yet the American Library Association came out against "locked shelves" in 1973. It reasoned that, although "the limitation [of closed stacks] differs from direct censorship activities, such as removal of library materials or refusal to purchase certain publications, it nonetheless constitutes censorship, albeit a subtle form." In cyberspace, censoring speech and selecting texts need not be two sides of a single coin. Each is a separate currency, censorship costing far more than selection. "The difference between choices to keep out and choices to throw out," Souter concluded, is "enormous."

\section{The Second-Best Thing about the Children's Internet Protection Act}

37 The best thing about the Children's Internet Protection Act is its intention: to keep kids safe. The second-best thing is that only four of nine justices could agree on a reason to uphold the law. When less than a majority of the Supreme Court concurs in the legal reasoning of an opinion, the result is a "plurality." A plurality decision does not make binding legal precedent. If it chooses, the Court can more quickly reverse its interpretation of the law. Keep your fingers crossed.

38 It feels appropriate - ironic and subversive - that I researched this article exclusively on the Internet. Sadly I could not do this work at a public library. Articles about filtering software often 
mention taboo terms like "pornography," which trigger filtering software to block access to the information. Even the text of the CIPA decision, written by the justices themselves, might be blocked by filters. And since I typed into this piece the word "pornography" (just did it again!), chances are that you are not reading this article in a public library. US v. ALA should not stand. Let us call on the Court to protect us from the Children's Internet Protection Act.

(c) Anna Lorien Nelson, 2004.

\section{References}

American Civil Liberties Union, Brief of Apellees, United States v. American Library Association, Inc., 201 F. Supp. 2d 401 (2003), February 10, 2003: http:/ archive.aclu.org court/ ala_brief.pdf. Accessed August 9, 2003.

American Library Association, Brief of Apellees, United States v. American Library Association, Inc., 201 F. Supp. 2d 401 (2003), February 10, 2003: http:// www.ala.org/ Content/ NavigationMenu/Our Association/Offices/ALA Washington/Issues2/Civil_Liberties, Intellectual Freedom,_Privacy/CIPA1/CIPA_Briefs/ meritsbrief.pdf. Accessed August 9, 2003.

American Library Association, "ALA Denounces Supreme Court Ruling on Children's Internet Protection Act," American Library Association, J une 23, 2003: http:// www.ala.org/ Template.cfm?Section $=$ News\&template $=/$ ContentManagement/ ContentDisplay.cfm\&ContentID = 36206. Accessed August 9, 2003.

"Colleges Turn to Web to Reduce Youth Suicide," CNN, October 6, 2003: http:// www.cnn.com. Accessed October 9, 2003.

"Franklin Library Faces Hard Times, But Won’t Close," Library J ournal, May 9, 2003: http:/ / libraryjournal.reviewnews. com. Accessed August 23, 2003.

Legal Information Institute, Cornell Law School, J uly 22, 2003 : http:// www.law.cornell.edu. Accessed August 9, 2003.

Supreme Court of the United States, J uly 23, 2003: http:// 
www.supremecourtus.gov. Accessed August 12, 2003.

Jim Tyre, "ACLU, ALA and Amici File Supreme Court Briefs Arguing that CIPA Is Unconstitutional," The Censorware Project, February 11, 2003: http:/ / censorware.net/ article.pl?sid=03/02/ 11/2043211\&tid=1. Accessed August 9, 2003.

United States v. American Library Association, Inc., 201 F. Supp. 2d 401 (2003). J une 23, 2003: http:// supct.law. cornell.edu/ supct/ html/ 02-361.ZO.html. Accessed August 9, 2003. 